\title{
Fundamentals of Delineation of Area of Mineral and hot Water Potential in Duyen Hai area, Hung Ha district, Thai Binh Province, Viet Nam for Exploration Purpose
}

\author{
Nguyen Van Hoang*, Le Quang Dao, Dong Thu Van, \\ Pham Lan Hoa, Vu Dinh Hai \\ ${ }^{1}$ Institute of Geological Sciences, Vietnam Academy of Science and Technology, \\ 84 Chua Lang, Lang Thuong, Dong Da, Hanoi, Vietnam
}

Received 26 September 2019

Revised 02 November 2019; Accepted 20 February 2020

\begin{abstract}
Mineral and hot water is a valuable resource that can be used for nursing and physiotherapy, making bottled water, making beverage and healing, exploiting useful minerals, energy extraction, even cultivation spirulina and other purposes. Hot groundwater was discovered during the 90s of the 20th century in Duyen Hai commune, Hung Ha district, Thai Binh province, but no exploration and evaluation studies were conducted to determine the potential of the mineral and hot water in the area. Spatial distribution of groundwater temperature and the total mineralization in the study area of the mineral and hot water occurrence and its surrounding area has allowed to identify the area of mineral and hot water origin, and that the hot water belongs to average hot water with a temperature of about 49 degrees Celsius. Analyzing the tectonic structure has showed that the mineral and hot water is formed at an area surrounded by three class- 2 faults, which have a vertical displacement amplitude of $100 \mathrm{~m}-1,000 \mathrm{~m}$ and a destructive zone of over $100 \mathrm{~m}$. This is an area with favorable conditions to bring geothermal source and dissolved minerals in surrounding rocks to groundwater in the above aquifers. The approach presented in the paper can be applied to conduct research on potential mineral and hot water in other areas: determine values of some mineral and hot water parameters such as temperature and TDS, compile maps of spatial distribution of the parameters, clarify characteristics of tectonic structure relevant to anomaly of high temperature and TDS.
\end{abstract}

Keywords: Groundwater, Hot mineral water, Geothermal, Dissolution, Fault, Tectonic structure, Spirulina.

\footnotetext{
* Corresponding author.

E-mail address: N_V_Hoang_VDC@yahoo.com

https://doi.org/10.25073/2588-1094/vnuees.4468
} 


\title{
Cơ sở khoa học xác định phân bố triển vọng nước khoáng nước nóng khu vực Duyên Hải, huyện Hưng Hà, tỉnh Thái Bình phục vụ thăm dò đánh giá tiềm năng
}

\author{
Nguyễn Văn Hoàng*, Lê Quang Đạo, Đông Thu Vân, \\ Phạm Lan Hoa, Vũ Đình Hải
}

Viện Địa chất-Viện Hàn lâm Khoa học và Công nghệ Việt Nam, 84 phố Chùa Láng, Láng Thuợng, Đống Đa, Hà Nội, Việt Nam

Nhận ngày 26 tháng 9 năm 2019

Chỉnh sửa ngày 02 tháng 11 năm 2020; Chấp nhận đăng ngày 20 tháng 02 năm 2020

\begin{abstract}
Tóm tắt: Nước khoáng $(\mathrm{NK})$, nước nóng $(\mathrm{NN})$ là một nguồn tài nguyên quý giá có thể được sử dụng trong điều dưỡng và vật lý trị liệu, làm nước đóng chai và chữa bệnh, khai thác các thành phần khoáng hóa trong nước, khai thác năng lượng, thậm chí nuôi tảo Spirulina và cho các mục đích khác... NK-NN được phát hiện trên khu vực xã Duyên Hải, huyện Hưng Hà, tỉnh Thái Bình từ những năm 90 của thế kỷ 20 nhưng chưa được tiến hành nghiên cứu đánh giá thăm dò nhằm xác định tiềm năng NK-NN ở khu vực. Nghiên cứu phân bố nhiệt độ và độ tổng khoáng hóa (TDS) của nước dưới đất (NDĐ) trên khu vực cho phép xác định được diện tích khu vực hình thành NK-NN và nước thuộc loại nóng trung bình với nhiệt độ khoảng $49^{\circ} \mathrm{C}$. Phân tích tương quan giữa khu vực NK-NN và hệ thống đứt gãy cùng cấu trúc kiến tạo cho thấy nguồn NK-NN này được hình thành tại khu vực bị bao bọc bởi 3 đứt gãy cấp 2, là những đứt gãy có biên độ dịch chuyển theo phương thẳng đứng 100 $\mathrm{m}-1.000 \mathrm{~m}$ và có đới phá huỷ trên $100 \mathrm{~m}$, là nơi có các điều kiện thuận lợi để đưa nguồn địa nhiệt từ phía sâu bên dưới lên và rửa lũa hòa tan các khoáng chất trong đất đá vây quanh tạo thành nguồn NK-NN ở tầng chứa nước bên trên. Các phương pháp trình bày trong bài báo có thể được áp dụng đối với các khu vực có tiềm năng về nước NN-NK khác là: điều tra khảo sát phân tích nhanh một số thông số liên quan đến NK-NN như nhiệt độ và TDS, xây dựng sơ đồ phân bố các thông số này theo diện, xác định các đặc điểm đặc trưng cấu trúc kiến tạo khu vực liên quan đến dị thường địa nhiệt.
\end{abstract}

Tù khoá: Nước dưới đất (NDĐ), nước khoáng-nước nóng (NKNN), địa nhiệt, rửa lũa, đứt gãy, cấu trúc kiến tạo, tảo Spirulina.

\section{Mở đầu}

Nước khoáng (NK), nước nóng (NN) (NK$\mathrm{NN}$ ) là một nguồn tài nguyên quý giá được con người nhận ra ý nghĩa thực tiễn trong việc điều trị một số loại bệnh: năm 1632, Ludovic Rowzee (Samanta Nunes and Bhertha Miyuki Tamura, 2012) [1] đã thành lập danh sách các loại bệnh có thể điều trị bằng nước, trong đó có các bệnh về xương khớp và rối loạn thần kinh. Từ đầu thế kỷ 17 đển nay, NK-NN được sử dụng rộng rãi trên khắp thế giới trong điều dưỡng và vật lý trị liệu, làm nước đóng chai, làm nước giải khát và chữa bệnh, khai thác các thành phần khoáng hóa trong nước, khai thác năng lượng và cho các mục đích khác,... Gần đây nhất, Vũ Thị Nguyệt và nnk. (2017) [2] đã tiến hành thí nghiệm nuôi cấy tảo Spirulina bằng NK Mỹ An, huyện Phú Vang,

\footnotetext{
* Tác giả liên hệ.

Địa chi email: N_V_Hoang_VDC@yahoo.com

https://doi.org/10.25073/2588-1094/vnuees.4468
} 
tỉnh Thừa Thiên Huế nhằm sử dụng hiệu quả nguồn bicarbonate và các khoáng chất có trong NK này.

Tổng hợp các nguồn tài liệu khác nhau cho thấy trên lãnh thổ nước ta có khoảng 400 nguồn nước khoáng, trong đó có 287 nguồn thuộc 12 loại hình nước khoáng đã được điều tra, có kết quả phân tích mẫu tương đối đầy đủ, đáng tin cậy được tổng hợp trong danh bạ NK Việt Nam (Võ Công Nghiệp (Chủ biên) và nnk, 1998 ) [3].

Trên địa bàn tỉnh Thái Bình, trong quá trình khoan thăm dò dầu khí cũng như thăm dò khai thác nước dưới đất (NDĐ) đã phát hiện nguồn NDĐ khoáng nóng trong các trầm tích cát, cuội, sỏi tuổi Pleistocen ở độ sâu gần $100 \mathrm{~m}$ và các trầm tích cổ hơn ở độ sâu vài trăm mét. Tuy nhiên, nguồn NDĐ khoáng nóng tại khu vực xã Duyên Hải, huyện Hưng Hà, tỉnh Thái Bình được phát hiện trước đây chưa được quan tâm nghiên cứu, điều tra, đánh giá về chất lượng nước, các khoáng chất hữu ích trong nước và hàm lượng của chúng, trữ lượng tài nguyên nguồn nước, quy mô phân bố, nguồn hình thành và nguồn bổ cập,... Vì vậy công tác nghiên cứu, trong đó có việc xác định khu vực trung tâm phân bố nguồn NK-NN của khu vực xã Duyên Hải, huyện Hưng Hà, tỉnh Thái Bình (Hình 1), là cần thiết để bắt đầu công tác thăm dò đánh giá tỷ mỷ về nguồn NK-NN của khu vực.

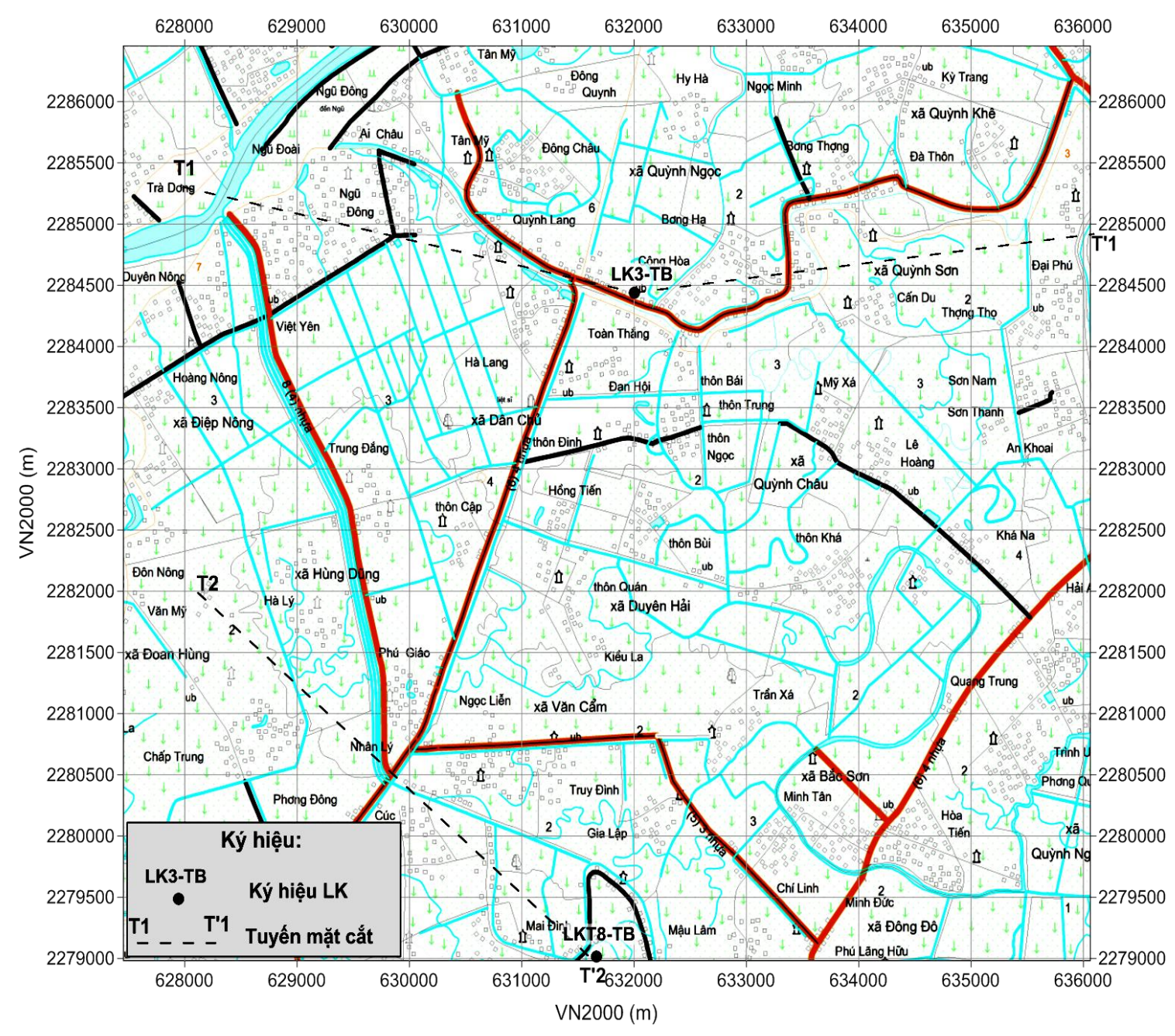

Hình 1. Bản đồ địa hình khu vực nghiên cứu NK-NN. 


\section{Phương pháp nghiên cứu}

Trong nghiên cứu này đã sử dụng các phương pháp nghiên cứu được sử dụng là: 1$)$ Thu thập tổng hợp các tài liệu (nhằm xác định cấu trúc địa chất thủy văn, các đứt gãy kiến tạo, đặc điểm hoạt động kiến tạo,...); 2) Điều tra khảo sát và đo đạc nhiệt độ, độ tổng khoáng hóa (TDS) và $\mathrm{pH}$ của NDĐ (bằng các thiết bị phân tích hiện trường); 3) Nội suy nhiệt độ và TDS của NDĐ và xây dựng sơ đồ đường đẳng trị nhiệt độ và TDS; 3 ) Phương pháp kế thừa (kế thừa các kết quả nghiên cứu về địa chất thủy văn, kiến tạo và địa nhiệt,...).

Thiết bị đo thực địa nhiệt độ, TDS và $\mathrm{pH}$ của NDĐ là máy Aquaprobe AP-7000, là thiết bị sử dụng các đâu đo chất lượng nước (Multiparameter Water Quality Probe and associated) của hãng Aquaread Ltd, Vương Quốc Anh (www.aquaread.com). NDĐ từ các LK được bơm lên và đo ngay các thông số này trong vài phút đầu. Sau đó NDĐ tiếp tục được bơm lên và được đo nhiệt độ liên tục. Sau một thời gian nhiệt độ đạt giá trị ổn định (trên thực tế điều tra khảo sát phân tích thì thời gian đạt ổn định nhiệt độ là 15-20 phút) các thông số này lại được đo và được xem là giá trị các thông số của NDĐ của tầng chứa nước ở độ sâu của ống lọc.

Vị trí khu vực nghiên cứu được xác định trên bản đồ cấu trúc kiến tạo khu vực nhằm xác định vị trí của khu vực NK-NN tương đối so với các thành phần cấu trúc kiến tạo (các đứt gãy và các khối cấu trúc kiến tạo) nhằm đánh giá các điều kiện có thể hình thành NK-NN.

\section{3. Đặc điểm địa chất, địa chất thủy văn và cấu trúc kiến tạo khu vực}

\section{1. Đặc điểm địa tầng}

Khu vực nghiên cứu có đặc điểm địa tầng từ Paleoproterozoi đến nay như sau.

- Paleoproterozoi, phức hệ sông Hồng: Plagiogneis biotit - granat - silimanit hạt nhỏ, vừa sẫm màu, gneis - biotit - silimanit - granat màu xám sáng và gneis biotit - silimanit - granat hạt vừa màu xám. Chiều dày tổng cộng của phức hệ khoảng $475 \mathrm{~m}$.
- Mesozoi, hệ Triat, hệ tầng Đồng Giao: đá vôi các loại tạo thành một nếp lõm không hoàn chỉnh, phần dưới là các đá vôi phân lớp mỏng màu đen xen sét vôi và bột kết vôi có góc đổ 30 - 50 độ. Các đá vôi này thường bị đứt gẫy theo hướng Tây Bắc-Đông Nam cắt qua làm cho đá vôi ở đây bị ép nén, nứt nẻ, dăm kết và tạo nên các đới dolomit hoá dọc theo các đứt gẫy. Chiều dày tổng cộng khoảng $720 \mathrm{~m}$.

- Kainozoi:

+ Hệ Paleogen: phần dưới gồm sét kết, bột kết, cát kết xen các thấu kính nhỏ cuội kêt, sỏi kết thuộc tướng lòng, tướng sườn. Sét kết ở đây bị ép nén mạnh tạo thành đá argilit rắn chắc. Trong đá còn quan sát thấy nhiều mạch thạch anh nhiệt dịch xuyên cắt làm cho đá bị biến đổi mạnh. Phần trên gồm cuội kết, sỏi kết, cát kết đa khoáng. Bề dầy của hệ tầng khoảng $540 \mathrm{~m}$.

+ Hệ Neogen: gồm cát kết hạt mịn đến trung, màu trắng, trắng xám, cát bột kết, sét bột kết màu xám đen, chứa nhiều ổ và các thấu kính than nâu. Bề dầy trầm tích trong các lỗ khoan biến đổi từ $1,885 \mathrm{~m}$ đến $3,280 \mathrm{~m}$.

+ Hệ Đệ Tứ: được chia thành Pleistocen (Pleistocen dưới có thành phần là cuội sỏi phân bố trong những đới sụt kiến tạo, kéo dài theo phương Tây Bắc - Đông Nam; Pleistocen giữatrên có thành phần là cát, sạn, sỏi lẫn cuội nhỏ, cát hạt nhỏ - trung, bột sét, bột sét hạt mịn; Pleistocen trên gồm cát lẫn sạn sỏi cuội nhỏ, cát hạt nhỏ lẫn bột, ít sét sạn sỏi nhỏ, sét bột, sét) và Holocen (Holocen dưới-giữa là trầm tích sông biển hạt mịn gồm sét bột; Holocen là trầm tích biển - sông gồm bột sét lẫn ít cát hạt mịn). Đây là các trầm tích tạo thành các tầng chứa nước và thấm nước yếu được mô tả cụ thể hơn ở phần dưới, trong đó NK-NN có mặt trong tầng chứa nước Pleistocen thượng-trung và Pleistocen hạ.

Cột địa tầng đặc trưng là cột địa tầng tại Quỳnh Côi được trình bày ở phụ lục.

\section{2. Đặc điểm địa chất thủy văn}

Các tầng chứa nước có ý nghĩa trên địa bàn tỉnh Thái Bình thuộc các trầm tích Đệ Tứ và theo thứ tự từ trên xuống dưới được mô tả tóm tắt theo Lại Đức Hùng và nnk (1996) [4], Châu Văn Quỳnh và nnk (1999) [5], Cao Sơn Xuyên (1985) [6] như sau: 
- Tầng chứa nước lỗ hổng Holocen trên $\left(\mathrm{qh}_{2}\right)$ : gồm các trầm tích thuộc hệ tầng Thái Bình (Hình 2 và 3 ) có nhiều nguồn gốc khác nhau: sông - biển, biển gió, biển, biển - đầm lầy, sông, hồ đầm lầy. Các trầm tích có các kiểu nguồn gốc khác nhau đều tạo thành lớp với chiều dày và thành phần đất đá, khả năng chứa nước, tính thấm nước rất khác nhau. Các thành tạo nguồn gốc biển, biển - gió và sông - biển có thành phần chủ yếu là cát lẫn ít bột. Tầng chứa nước này có chiều dày không lớn, thành phần đất đá đa nguồn gốc nên mức độ thấm nước không đồng đều và thuộc loại nghèo nước.

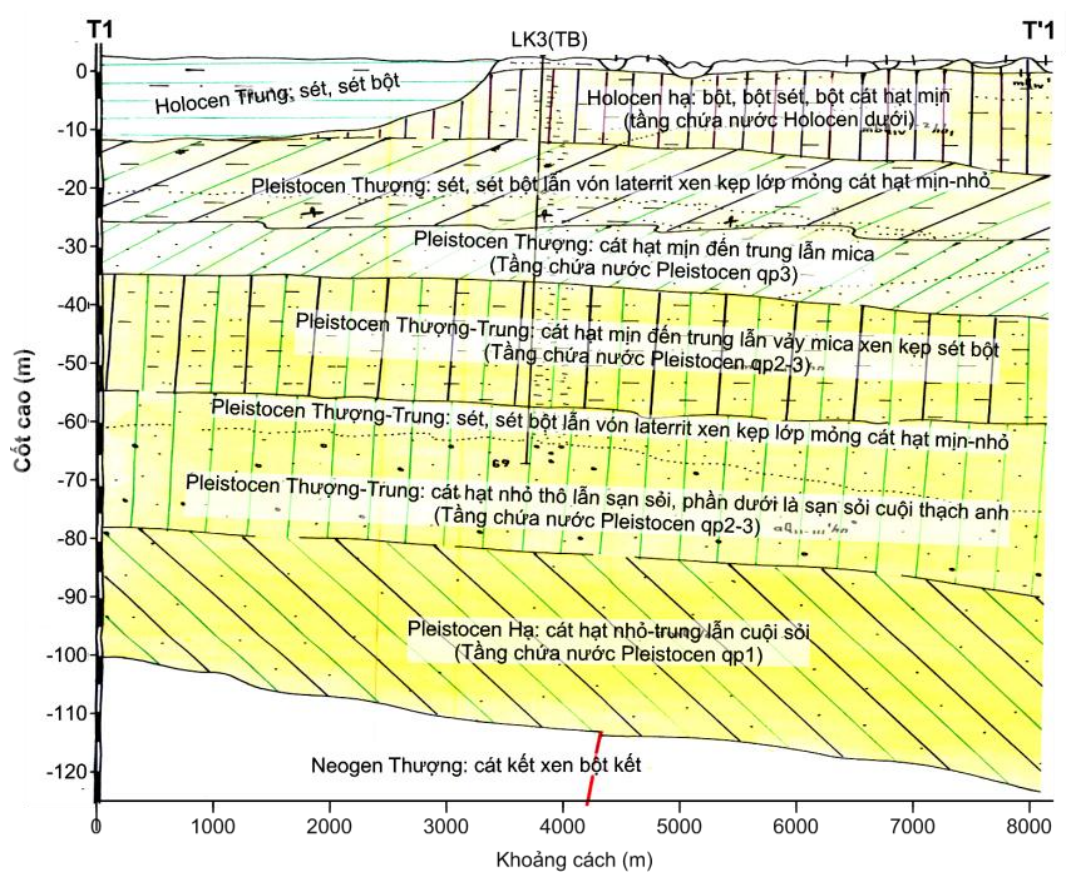

Hình 2. Mặt cắt T1-T'1 hướng từ Tây sang Đông phía Bắc khu vực nghiên cứu [7].

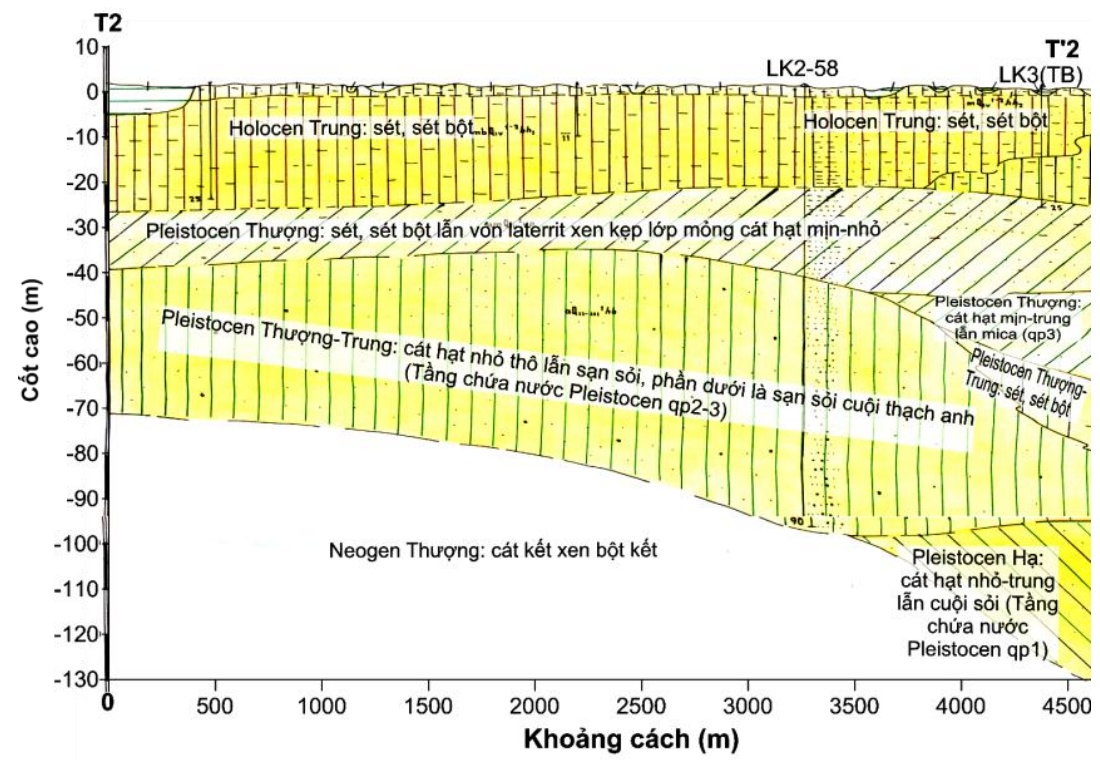

Hình 3. Mặt cắt T2-T'2 hướng từ TB-ĐN khu vực nghiên cứu [7]. 
- Tầng chứa nước lỗ hổng Holocen dưới $\left(\mathrm{qh}_{1}\right)$ : được tạo thành bởi các trầm tích bở rời của các trầm tích hệ tầng Hải Hưng là cát thạch anh hạt nhỏ màu xám đen, xám vàng chứa mica và dấu tích động thực vật. Tầng chứa nước này được ngăn cách với tầng chứa nước $\mathrm{qh}_{2}$ phía trên bởi các trầm tích tương đối cách nước thuộc phần trên của hệ tầng Hải Hưng (Hình 2 và 3 ). Tầng chứa nước $\mathrm{qh}_{1}$ này cũng được ngăn cách với tầng chứa nước Pleistocen phía dưới bằng các lớp sét, sét bột của trầm tích hệ tầng Vĩnh Phúc. Chiều sâu mái và chiều dày của tầng chứa nước thay đổi trong phạm vi lớn. Tầng chứa nước $\mathrm{qh}_{1}$ có chất lượng kém, hầu hết các lỗ khoan trong tầng chứa nước này đều gặp nước mặn.

- Tầng chứa nước lỗ hổng Pleistocen (qp): được tạo thành bởi đất đá bở rời thuộc phần dưới của hệ tầng Vĩnh Phúc, đất đá của hệ tầng Hà Nội và hệ tầng Lệ Chi. Thành phần của đất đá chứa nước của tầng chứa nước này là cát hạt mịn, trung, thô, cuội sỏi, cuội lẫn sét phân bố theo thứ tự từ trên xuống dưới.

Các trầm tích của tầng chứa nước qp (Hình 2 và 3) nằm trực tiếp phía trên các trầm tích Neogen và bị các trầm tích hạt mịn cách nước thuộc phần trên của hệ tầng Vĩnh Phúc phủ lên trên. Chiều sâu bắt gặp các trầm tích này từ $26 \mathrm{~m}$ đến $143 \mathrm{~m}$. Chiều dày tầng chứa nước thay đổi từ $29 \mathrm{~m}$ đến $127 \mathrm{~m}$. Tầng chứa nước Pleistocen còn được phân ra tầng chứa nước Pleistocen thượng $\left(\mathrm{qp}_{3}\right)$, tầng chứa nước Pleistocen thượngtrung $\left(\mathrm{qp}_{2-3}\right)$ và tầng chứa nước Pleistocen hạ $\left(\mathrm{qp}_{1}\right)$. Đây là tầng chứa nước mà tại khu vực xã Duyên Hải huyện Hưng Hà tỉnh Thái Bình cho nước nóng.

\subsection{Hệ thống đứt gãy và cấu trúc kiến tạo}

Khu vực đồng bằng Sông Hồng có hệ thống các đứt gãy khá phức tạp, hình thành ở những giai đoạn khác nhau, và được chia thành hai hệ thống sau (Hình 4) (Lại Mạnh Giàu, 2017) [8]:

- Hệ thống đứt gãy phương Tây Bắc- Đông Nam: là hệ thống đứt gãy chính khống chế bình đồ cấu trúc vùng trũng Sông Hồng gồm các đứt gãy thuận trượt bằng ngang Sông Hồng và sông Lô; đứt gãy nghịch Vĩnh Ninh, đứt gãy thuận Thái Bình, đứt gãy sông Chảy,... Các đứt gãy có góc cắm 70- 80 độ với biên độ dịch chuyển 100 m - 1,000 m, đới phá huỷ trên 100 m. Hệ thống đứt gãy trên bắt đầu hoạt động sớm, sau đó tái hoạt động cho đến cuối Miocen muộn thì ngừng hoạt động, chúng ảnh hưởng lớn đến sự hình thành cấu trúc địa chất Kainozoi và tạo ra những khối nâng, khối sụt làm vùng trũng Sông Hồng trở thành một địa hào lớn lấp đầy trầm tích Neogen.

- Hệ thống đứt gãy phương Đông Bắc - Tây Nam: là các đứt gãy Đồng Văn - Kẻ Sặt, Hưng Yên - Hải Dương,... Các đứt gãy này hoạt động tích cực trong giai đoạn đồng tạo rift và là những đứt gãy thuận thuộc các pha căng giãn Eocen muộn-Oligocen sớm và đầu Miocen sớm hoặc đứt gãy nghịch hay trượt bằng thuộc pha nén ép Oligocen muộn và cuối Miocen sớm. Hệ thống đứt gãy này phân chia các khối kiến trúc thành những khối nhỏ có dạng bậc thang, tụt dần về phía biển, làm gián đọan hoặc dịch chuyển hệ thống đứt gãy phương Tây Bắc-Đông Nam. Biên độ dịch chuyển của các đứt gãy này không lớn: từ vài mét đến vài chục mét.

\section{4. Đăc điểm phân bố nhiệt độ và TDS của nguồn NK-NN khu vực nghiên cứu}

Hai chỉ tiêu cơ bản được sử dụng để đánh giá xác định diện phân bố tập trung nguồn NK-NN khu vực nghiên cứu là nhiệt độ nước và TDS. Chỉ tiêu nhiệt độ là một chỉ tiêu đương nhiên được sử dụng khi nghiên cứu nước nóng, và chỉ tiêu độ tổng khoáng hóa được sử dụng để đánh giá khả năng rửa lũa hòa tan các khoáng chất tạo thành nước khoáng. Theo kết quả phân tích phân bố TDS của NDĐ trên khu vực, TDS nền của NDĐ ở đây là khoảng $420 \mathrm{mg} / \mathrm{l}$. Với giả thiết là NK-NN ở đây có nguồn gốc rửa lũa-pha trộn: NDĐ của tầng chứa nước Pleistocen được pha trộn với nước có nhiệt độ cao và một số thành khoáng hóa được vận chuyển lên từ sâu phía dưới lên. 


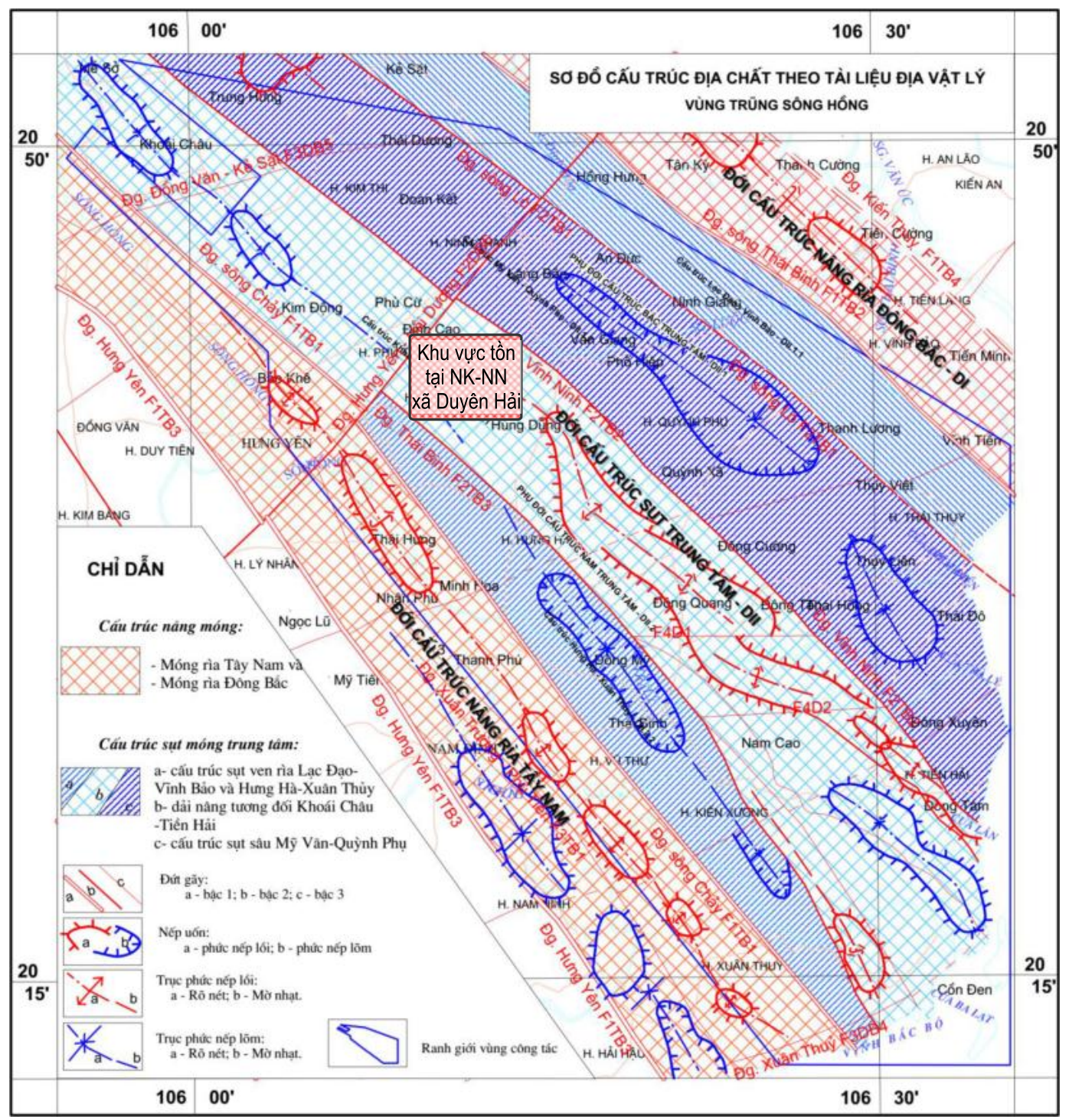

Hình 4. Sơ đồ cấu trúc địa chất trũng Sông Hồng (Lại Mạnh Giàu, 2017) [8].

Điều tra khảo sát đánh giá sự phân bố nhiệt độ và độ tổng khoáng hóa của NDĐ khu vực nghiên cứu được tiến hành thông qua số liệu đo đạc và khảo sát ở 80 lỗ khoan (LK) khai thác NDĐ tầng Pleistocen hiện có trên khu vực nghiên cứu. Vị trí, độ sâu 80 LK khảo sát, nhiệt đô, $\mathrm{pH}$ và $\mathrm{TDS}$ của NDĐ trong các $\mathrm{LK}$ trình bày trong phụ lục. Các LK khảo sát đều có độ sâu nhỏ nhất là $40 \mathrm{~m}$ (mái của tầng chứa nước Pleistocen ở độ sâu khoảng $38 \mathrm{~m}$ ) đến lớn nhất là $105 \mathrm{~m}$ (đáy của tầng chứa nước Pleistocen ở độ sâu 100 m đến trên 130 m) (Hình 2 và 3 ). Ống lọc của các LK dài khoảng $10 \mathrm{~m}$ đều ở phần gần cuối $\mathrm{LK}$, mà phía dưới là ống lắng dài khoảng 1 $2 \mathrm{~m}$.

Ban đầu, NDĐ trong các LK không được bơm lên sẽ có nhiệt độ thấp hơn NK-NK nằm sâu phía dưới do tiếp xúc với chiều dày lớn NDĐ có nhiệt độ thấp phía trên. NDĐ được bơm lên và được đo nhiệt độ liên tục tới khi nhiệt độ tăng lên đạt ổn định. Phân bố nhiệt độ NDĐ trên khu vực nghiên cứu và khu vực trung tâm hình thành nguồn NK-NN (dị thường cao về nhiệt độ và TDS) thể hiện tương ứng trên Hình 5 và 7 . 
Tương tự, phân bố TDS của NDĐ trên khu vực nghiên cứu và khu vực dị thường cao về nhiệt độ và TDS thể hiện tương ứng trên Hình 6 và 8 . Thay đổi nhiệt độ và TDS theo tuyến mặt cắt Bắc-Nam $\mathrm{AB}$ qua tâm khu vực dị thường được thể hiện trên Hình 9. TDS của NDĐ ở khu vực tâm dị thường nhiệt độ là khoảng $340 \mathrm{mg} / \mathrm{l}$ thấp hơn khoảng $19 \%$ so với khu vực xung quanh có giá trị khoảng $420 \mathrm{mg} / \mathrm{l}$.

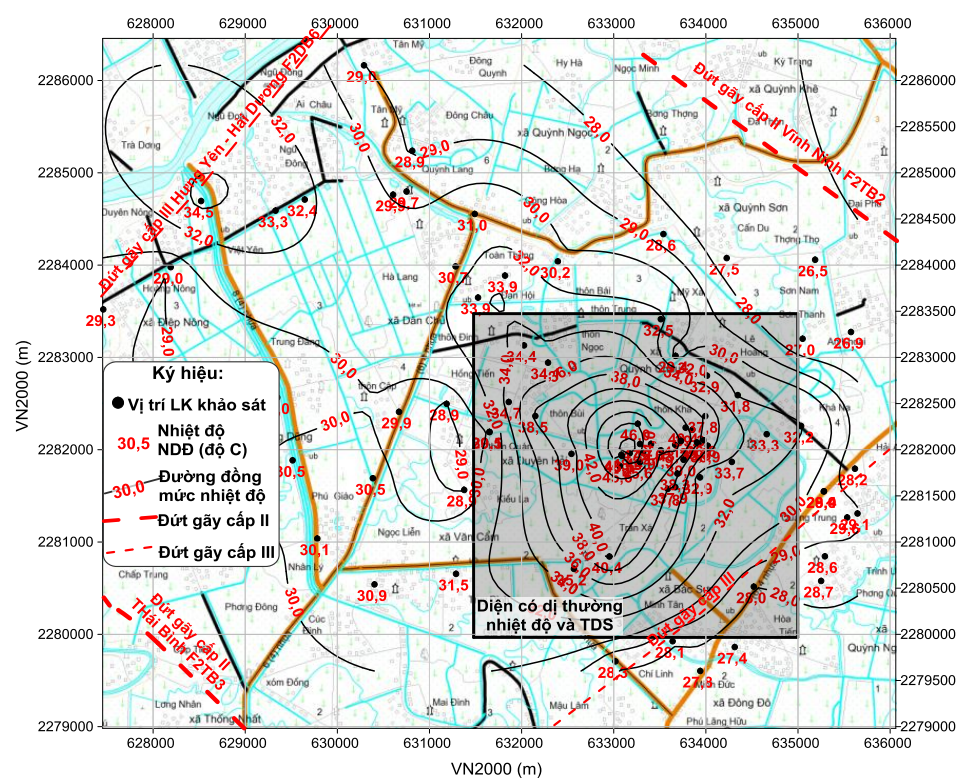

Hình 5. Phân bố nhiệt độ NDĐ tầng chứa nước Pleistocen trên diện khảo sát (tháng 8/2019).

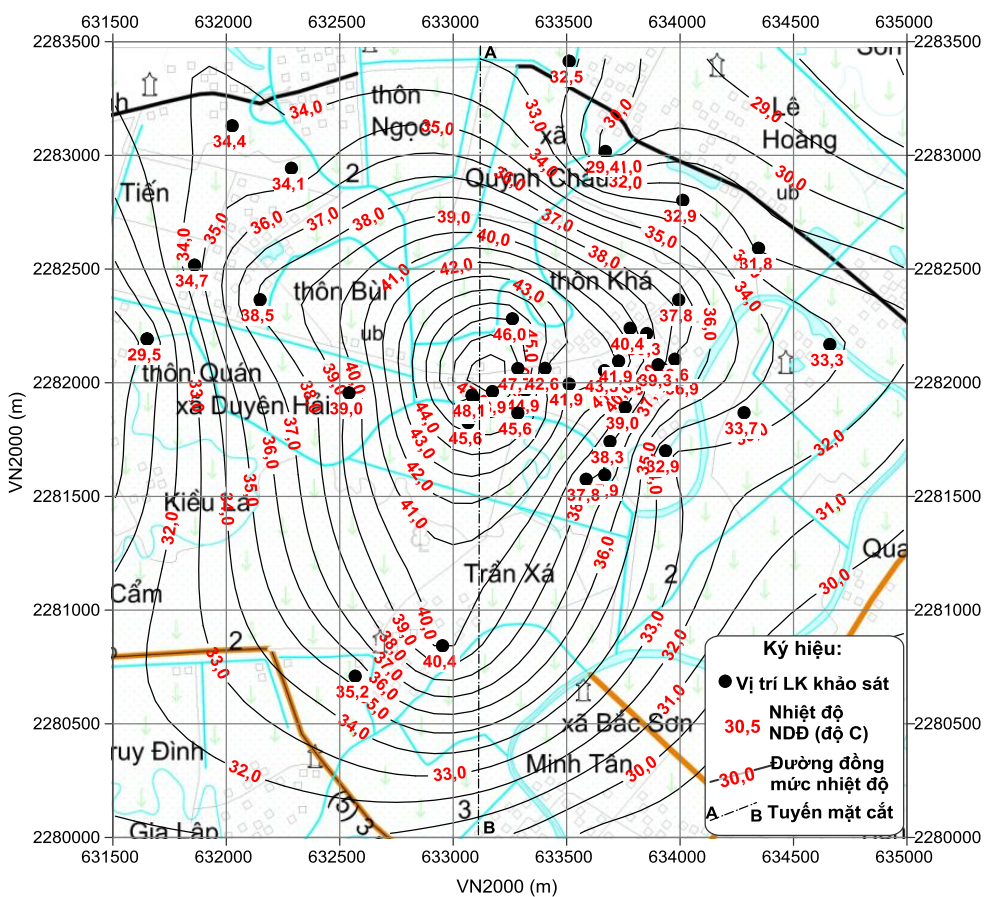

Hình 6. Phân bố nhiệt độ NDĐ tầng chứa nước Pleistocen trên diện có dị thường nhiệt độ và TDS (tháng 8/2019). 


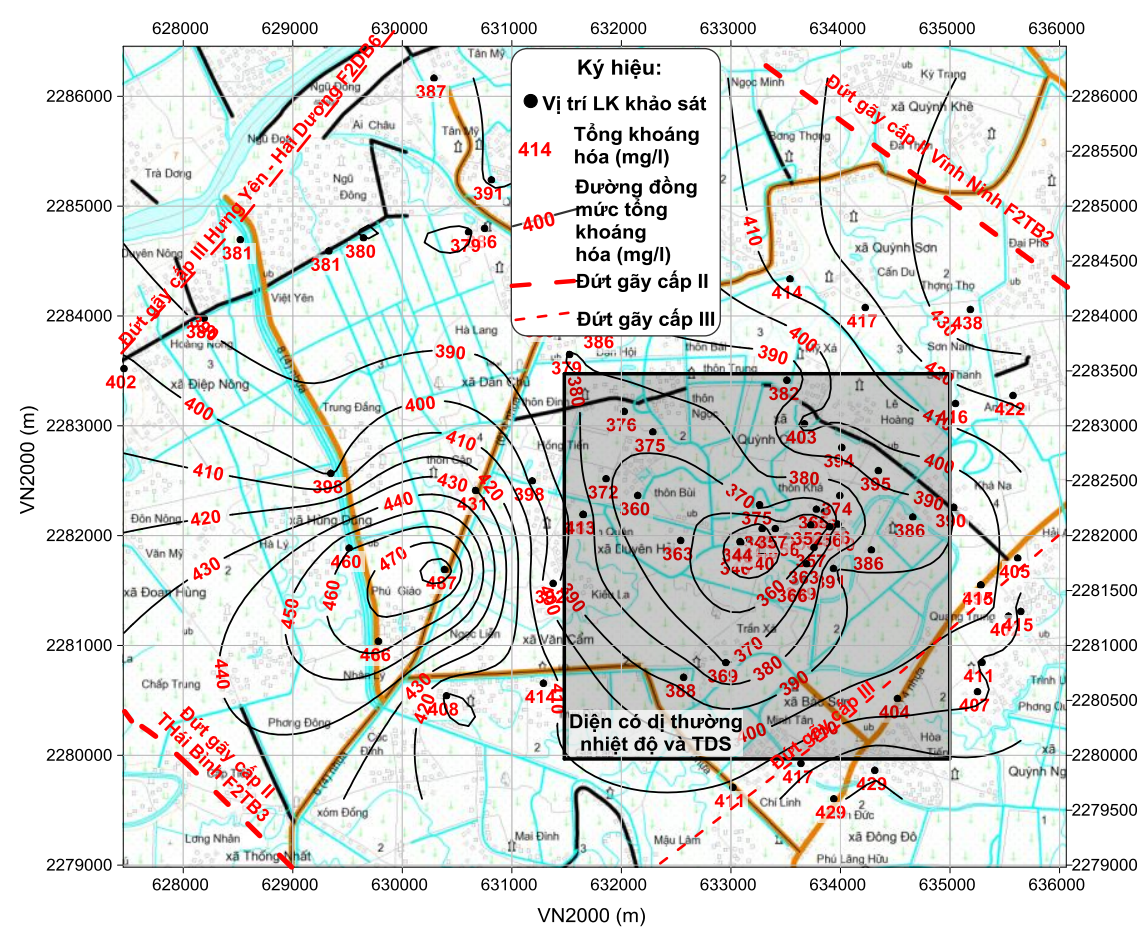

Hình 7. Phân bố TDS NDĐ tầng chứa nước Pleistocen trên diện khảo sát (tháng 8/2019).

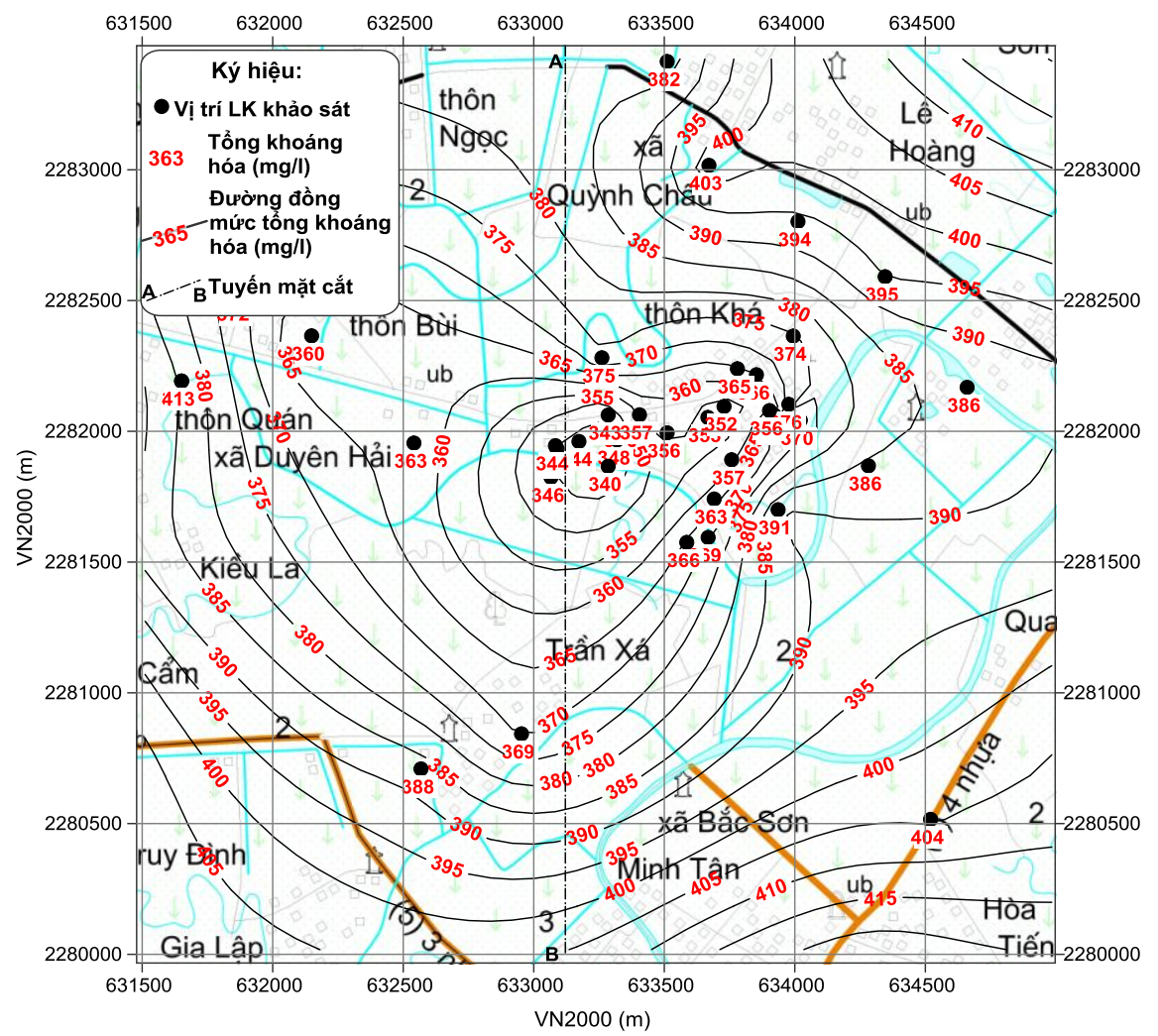

Hình 8. Phân bố TDS NDĐ tầng chứa nước Pleistocen trên diện có dị thường nhiệt độ và TDS (tháng 8/2019). 


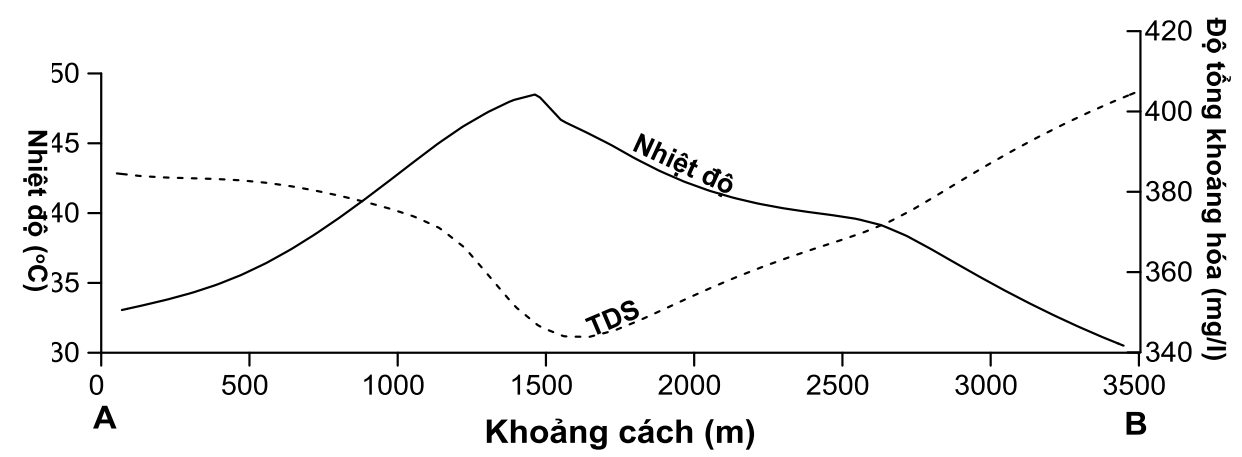

Hình 9. Phân bố nhiệt độ và TDS NDĐ qua tâm khu vực dị thường nhiệt độ (tháng 8/2019).

\section{Về mối tương quan giữa nguồn NKNN với đứt gãy và phân đới cấu trúc}

Trên trũng sông Hồng các đứt gãy với quy mô, phương phát triển khác nhau cả về chiều dài cũng như biên độ dịch chuyển có phân bậc như sau:

- Đứt gãy cấp I (F1) là loại đứt gãy phát triển sâu nhất trong vùng, có biên độ dịch chuyển lớn. Đứt gãy có vai trò phân đới cấu trúc hoặc miền kiến tạo. Đó là các đứt gãy Hưng Yên (F1TB3), đứt gãy Sông Chảy (F1TB1), đứt gãy sông Thái Bình (F1TB2) và đứt gãy Kiến Thụy (F1TB4) nằm cách xa khu vực hình thành nguồn NK-NN là $15 \mathrm{~km}$ đến $20 \mathrm{~km}$ (Hình 4).

- Đứt gãy cấp II (F2) là loại đứt gãy sâu, có biên độ dịch chuyển trung bình đến lớn, có vai trò khống chế các dải nâng, dải sụt. Có 3 đứt gãy loại này bao bọc khu vực hình thành NK-NN là đứt gãy Hưng Yên-Hải Dương (F2DB5), đứt gãy Thái Bình (F2TB3) và đứt gãy Vĩnh Ninh (F2TB2) (Hình 4).

- Đứt gãy cấp III (F3) là loại đứt gãy nội tầng hoặc những đứt gãy kéo theo của loại đứt gãy sâu (cấp I và cấp II), có thể tham gia vào quá trình hình thành nên bình đồ cấu trúc địa chất vùng nghiên cứu, tạo nên các khối nâng, khối sụt. Trên khu vực nghiên cứu có đứt gãy loại này ở sát phía Đông Nam khu vực hình thành NK-NN (Hình 5 và 7$)$.

Trên phương diện phân đới cấu trúc thì khu vực có nguồn NK-NN trong tầng chứa nước Pleistocen dưới nằm ở khoảng giữa dải nâng tương đối Khoái Châu-Tiền Hải và nằm trên trục của nếp uốn lồi ở dải này (Hình 4).

Như vậy có thể thấy rằng NK-NN trong tầng chứa nước Pleistocen dưới (là tầng chứa nước phân bố rộng khắp trên đồng bằng Bắc Bộ) tại xã Duyên Hải huyện Hưng Hà tỉnh Thái Bình được hình thành tại nơi bị bao bọc bởi 3 đứt gãy cấp 2 , là những đứt gãy có biên độ dịch chuyển lên xuống $100 \mathrm{~m}-1,000 \mathrm{~m}$ và có đới huỷ hoại trên 100 m (Lại Mạnh Giàu, 2017) [8] là nơi có các điều kiện thuận lợi để đưa nguôn địa nhiệt từ phía sâu bên dưới lên và rửa lũa hòa tan các khoáng chất trong đất đá vây quanh.

Điều này còn được thể hiện qua kết quả nghiên cứu của Đinh Văn Toàn (1995) [9] bằng phương pháp địa nhiệt và đo sâu điện khu vực xã Duyên Hải cho kết quả là nhiệt độ NDĐ cao tới $35^{\circ} \mathrm{C}-48^{\circ} \mathrm{C}$ là liên quan đến đứt gãy Vĩnh Ninh và đứt gãy Tiên Hưng. Tác giả cũng đã xác định được nhiệt độ NDĐ cao nhất cao nhất là $48^{\circ} \mathrm{C}$ nằm trên đứt gãy Vĩnh Ninh, và tại khu vực có gradient địa nhiệt là $20^{\circ} \mathrm{C} / 100 \mathrm{~m}$.

\section{Kết luận và kiến nghị}

Từ kết quả nghiên cứu được trình bày ở trên, có đưa ra một số nhật xét kết luận như sau:

- Nguồn NK-NN xã Duyên Hải huyện Hưng Hà tỉnh Thái Bình được hình thành theo cơ chế rửa lũa tại nơi đá gốc bị phá hủy bởi các hoạt động kiến tạo cũng như tại chính các đứt gãy;

- NK-NN thuộc loại nước nóng vừa (là nước có nhiệt độ $41-60^{\circ} \mathrm{C}$ ) (Võ Công Nghiệp chủ biên) và nnk, 1998 [3] có nhiệt độ $\sim 49^{\circ} \mathrm{C}$; 
- NK-NN có TDS từ khoảng $340 \mathrm{mg} / \mathrm{l}$ đến khoảng trên $420 \mathrm{mg} / \mathrm{l}$ trong khi khu vực xung quanh NDĐ có TDS trên dưới $420 \mathrm{mg} / \mathrm{l}$;

- Khu vực nguồn NK-NN có kích thước khoảng $4 \mathrm{~km} \times 4 \mathrm{~km}$ với giới hạn rìa nguồn có nhiệt độ khoảng $30^{\circ} \mathrm{C}$.

Để nghiên cứu đánh giá loại hình hóa học của nguồn NK-NN cũng như trữ lượng của nguồn NK-NN này cần tiển hành xây dựng chùm lỗ khoan thí nghiệm tại trung tâm khu vực hình thành nguồn NK-NN và thực hiện hút nước thí nghiệm kết hợp ép chất chỉ thị nhằm đánh giá định lượng sự thay đổi nhiệt độ và các khoáng chất của NK-NN cũng như quá trình lan truyền của chúng trong quá trình thí nghiệm, và phân tích các thành phần hóa học của nước và hàm lượng các khoáng chất vi nguyên tố trong nguồn nước NK-NN nghiên cứu. Các số liệu thí nghiệm là cơ sở để thực hiện xác định các thông số lan truyền khoáng chất trong NDĐ của tầng chứa NK-NN và đại lượng nguồn nhiệt và khoáng chất được rửa lũa cung cấp hòa trộn với NDĐ để hình thành nguồn NK-NN.

Ngoài ra, cách tiếp cận và phương pháp tiến hành được trình bày trong bài báo có thể được áp dụng để tiến hành nghiên cứu các khu vực có khả năng về nước NN-NK ở các khu vực khác.

\section{Lời cảm ơn}

Bài viết được hoàn thành trong khuôn khổ đề tài khoa học cồng nghệ "Nghiên cứu tiềm năng nguồn nước (khoáng) nóng thiên nhiên khu vực Duyên Hải, Hưng Hà, tỉnh Thái Bình và đề xuất phương hướng khai thác và sử dụng hiệu quả" có mã số TB-CT/CN02/19-20.

\section{Tài liệu tham khảo}

[1] Samanta Nunes and Bhertha Miyuki Tamura, A historical review of mineral water. Surg Cosmet Dermatol 4(3) (2012) 252-258.

[2] Vu Thi Nguyet, Dang Dinh Kim, Nguyen Hong Chuyen, Vu Thi Thanh Tam, Tran Phuong Ha, Pham Viet Cuong, Ton That Huu Dat, Hoang Phan Bich Ngoc, Nguyen Thi Thu Thuy, Experimental cultivation of Spirulina platensis using My An mineral water, Thua Thien Hue province. Vietnam Journal of Science and Technology 55 (5) (2017) 548 -556. http://doi.org/10.15625/2525-2518/55/5/9374.

[3] Vo Cong Nghiep (editor), Pham Van Bay, Ngo Ngoc Cat, Phan Ngoc Cu, Catalogue of natural mineral and hot water sources in Vietnam. Ministry of Natural Resources and Environment (1998) (in Vietnamese).

[4] Lai Duc Hung (editor), Report on 1:50,000 scale hydrogeological mapping for Thai Binh area. Ministry of Natural Resources and Environment (1996) (in Vietnamese).

[5] Chau Van Quynh (editor), Report on hydrogeological mapping for Thai Binh urban area. Ministry of Natural Resources and Environment (1999) (in Vietnamese).

[6] Cao Son Xuyen, Dinh-Thai Binh area. Ministry of Natural Resources and Environment (1985) (in Vietnamese).

[7] Union of Geological Mapping, Report on 1:50,000 scale geology and mineral resources exploration mapping for Nam Dinh-Thai Binh area. Ministry of Natural Resources and Environment (1996) (in Vietnamese).

[8] Lai Manh Giau, Study on characteristics of geological structure of Red River basin based on geophysical data for coal resource investigation. $\mathrm{PhD}$ thesis. Hanoi University of Mining and Geology (2017) (in Vietnamese).

[9] Dinh Van Toan, Results of hot water source survey by a combination of geothermal method and vertical electric sounding in Duyen Hai commune, Hung Ha district, Thai Binh province. Vietnam Academy of Science and Technology (1995) (in Vietnamese). 


\section{Phụ lục 1: Cột địa tầng đặc trưng: Quỳnh Côi}

\section{CỘT Đị̂A TÀNG \\ TÖ F - 48 - 129 - B ( QUY̌NH CÔI) \\ T̛̉ㄴํํ $1: 500$}

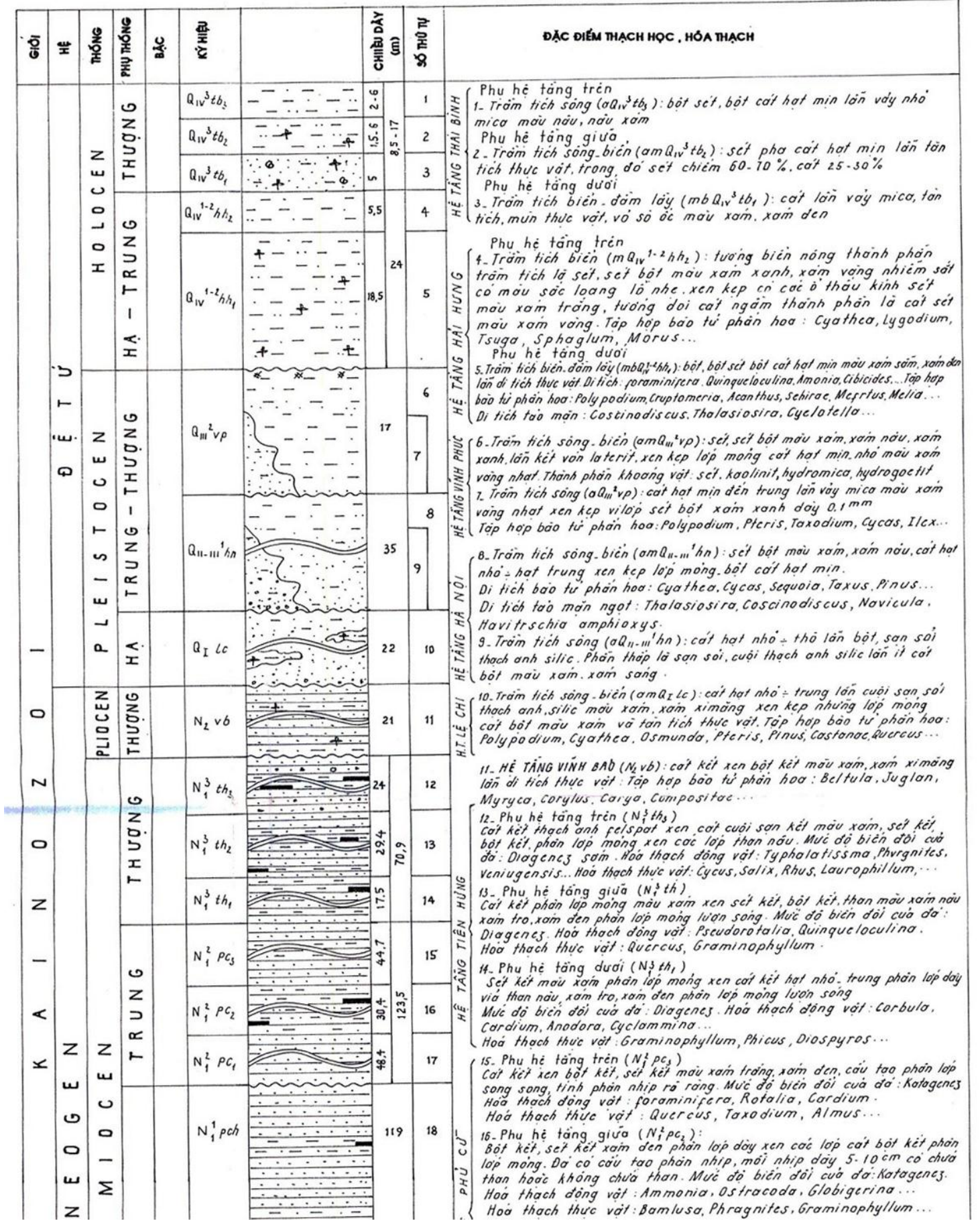


Phụ lục 2: Vị trí và độ sâu các LK khảo sát, nhiệt độ, pH và TDS NDĐ trong các LK

\begin{tabular}{|c|c|c|c|c|c|c|c|}
\hline \multirow{2}{*}{ TT } & \multirow{2}{*}{ Họ và tên-địa chỉ } & \multicolumn{2}{|c|}{ Tọa độ (VN2000) } & \multirow{2}{*}{$\begin{array}{l}\text { Chiều sâu } \\
\text { LK (m) }\end{array}$} & \multirow{2}{*}{$\begin{array}{c}\text { Nhiệt độ } \\
\left({ }^{\circ} \mathbf{C}\right)\end{array}$} & \multirow{2}{*}{ pH } & \multirow{2}{*}{$\begin{array}{r}\text { TDS } \\
(\mathrm{mg} / \mathrm{l})\end{array}$} \\
\hline & & $\mathrm{X}(\mathrm{m})$ & $\mathrm{Y}(\mathrm{m})$ & & & & \\
\hline 1 & $\begin{array}{l}\text { Trần Văn Hộ-Hải An, xã Quỳnh Nguyên, } \\
\text { huyện Quỳnh Phụ }\end{array}$ & 635534 & 2281266 & 75 & 29,6 & 7,83 & 401,9 \\
\hline 2 & $\begin{array}{l}\text { Nguyễn Văn Xanh-thôn Phương Quả, xã } \\
\text { Quỳnh Nguyên, huyện Quỳnh Phụ }\end{array}$ & 635292 & 2280845 & 100 & 28,6 & 7,27 & 411,5 \\
\hline 3 & $\begin{array}{l}\text { Khổng Minh Lý-thôn Phương Quả Đông, } \\
\text { xã Quỳnh Nguyên, huyện Quỳnh Phụ }\end{array}$ & 635251 & 2280578 & 80 & 28,7 & 7,25 & 407,2 \\
\hline 4 & $\begin{array}{l}\text { Cửa hàng tạp hóa Tình Bảo xã Quỳnh } \\
\text { Nguyên, huyện Quỳnh Phụ }\end{array}$ & 635281 & 2281549 & 70 & 29,4 & 7,25 & 395,3 \\
\hline 5 & $\begin{array}{l}\text { Quán gà, ngã ba chợ Hới-Quỳnh Nguyên, } \\
\text { huyện Quỳnh Phụ }\end{array}$ & 635281 & 2281549 & 80 & 28,9 & 7,23 & 415,1 \\
\hline 6 & $\begin{array}{l}\text { Đoàn Huy Trọng-xóm } 2 \text { Hải An, xã } \\
\text { Quỳnh Nguyên, huyện Quỳnh Phụ }\end{array}$ & 635646 & 2281309 & 80 & 29,1 & 7,23 & 415,3 \\
\hline 7 & $\begin{array}{l}\text { Nguyễn Văn Tuế-Hải An, xã Quỳnh } \\
\text { Nguyên, huyện Quỳnh Phụ }\end{array}$ & 635618 & 2281794 & 70 & 28,2 & 7,08 & 405,1 \\
\hline 8 & $\begin{array}{l}\text { Lưu Xuân Bắc-thôn Khả Nang, xã Quỳnh } \\
\text { Châu, huyện Quỳnh Phụ }\end{array}$ & 635034 & 2282257 & 85 & 32,2 & 7,43 & 390,0 \\
\hline 9 & $\begin{array}{l}\text { Đoàn Ngọc Thạch-thôn Khả Nang, xã } \\
\text { Quỳnh Châu, huyện Quỳnh Phụ }\end{array}$ & 634660 & 2282168 & 70 & 33,3 & 7,34 & 385,9 \\
\hline 10 & $\begin{array}{l}\text { Bùi Văn Đoàn-thôn Châu Duyên, xã } \\
\text { Quỳnh Châu, huyện Quỳnh Phụ }\end{array}$ & 634282 & 2281868 & 80 & 33,7 & 7,48 & 385,8 \\
\hline 11 & $\begin{array}{l}\text { Nguyễn Văn Huynh-thôn Khả, xã Duyên } \\
\text { Hải, huyện Hưng Hà }\end{array}$ & 633936 & 2281700 & 75 & 32,9 & 7,34 & 390,9 \\
\hline 12 & $\begin{array}{l}\text { Nguyễn Văn Tạc-thôn Hoàng Xá, xã } \\
\text { Quỳnh Châu, huyện Quỳnh Phụ }\end{array}$ & 634346 & 2282591 & 92 & 31,8 & 7,27 & 395,2 \\
\hline 13 & $\begin{array}{l}\text { Nguyễn Văn Trung-thôn Phúc Lễ, xã } \\
\text { Quỳnh Châu, huyện Quỳnh Phụ }\end{array}$ & 634012 & 2282802 & 70 & 32,9 & 7,32 & 393,7 \\
\hline 14 & $\begin{array}{l}\text { Trần Thị Bắc-xóm } 7 \text { xã Quỳnh Châu, } \\
\text { huyện Quỳnh Phụ }\end{array}$ & 633671 & 2283017 & 120 & 29,4 & 6,8 & 403,0 \\
\hline 15 & $\begin{array}{l}\text { Nguyễn Thị Quy-thôn Mỹ Xá, xã Quỳnh } \\
\text { Châu, huyện Quỳnh Phụ }\end{array}$ & 633511 & 2283414 & 65 & 32,5 & 7,27 & 381,7 \\
\hline 16 & $\begin{array}{l}\text { Bùi Văn Sinh-thôn Khả Đông, xã Duyên } \\
\text { Hải, huyện Hưng Hà }\end{array}$ & 633668 & 2281594 & 70 & 37,9 & 7,15 & 369,4 \\
\hline 17 & $\begin{array}{l}\text { Vũ Quang Thông-thôn Khả Đông, xã } \\
\text { Duyên Hải, huyện Hưng Hà }\end{array}$ & 633586 & 2281575 & 70 & 37,8 & 7,48 & 365,7 \\
\hline 18 & $\begin{array}{l}\text { Nguyễn Văn Dự-thôn Khả Tiến, xã } \\
\text { Duyên Hải, huyện Hưng Hà }\end{array}$ & 633667 & 2282053 & 80 & 43,3 & 7,25 & 353,3 \\
\hline 19 & $\begin{array}{l}\text { Nguyễn Hữu Dũng, thôn Khả Tân, xã } \\
\text { Duyên Hải, huyện Hưng Hà }\end{array}$ & 633511 & 2281994 & 75 & 41,9 & 7,3 & 356,5 \\
\hline 20 & $\begin{array}{l}\text { Lê Thị Cã, thôn Khả Tân, xã Duyên Hải, } \\
\text { huyện Hưng Hà }\end{array}$ & 633319 & 2281967 & 70 & 44,9 & 7,57 & 347,6 \\
\hline 21 & $\begin{array}{l}\text { Lê Xuân Hận-(sát chợ) Khả Tân, xã } \\
\text { Duyên Hải, huyện Hưng Hà }\end{array}$ & 633173 & 2281961 & 75 & 48,9 & 7,56 & 343,9 \\
\hline
\end{tabular}




\begin{tabular}{|c|c|c|c|c|c|c|c|}
\hline 22 & $\begin{array}{l}\text { Hộ Đỗ Tiên Liểu- Khả Tân, xã Duyên } \\
\text { Hải, huyện Hưng Hà }\end{array}$ & 633066 & 2281824 & 90 & 45,6 & 7,32 & 345,6 \\
\hline 23 & $\begin{array}{l}\text { Trịnh Văn Hạnh- Khả Tân, xã Duyên Hải, } \\
\text { huyện Hưng Hà }\end{array}$ & 633285 & 2281866 & 70 & 45,6 & 7,52 & 339,9 \\
\hline 24 & $\begin{array}{l}\text { Đỗ Văn Lương- Khả Tiến, xã Duyên Hải, } \\
\text { huyện Hưng Hà }\end{array}$ & 633261 & 2282281 & 72 & 46,0 & 7 & 374,9 \\
\hline 25 & $\begin{array}{l}\text { Bùi Văn Thuấn- Khả Tân, xã Duyên Hải, } \\
\text { huyện Hưng Hà }\end{array}$ & 633285 & 2282062 & 75 & 47,7 & 7,52 & 343,1 \\
\hline 26 & $\begin{array}{l}\text { Nguyễn Thiện Cầm- Khả Đông, xã } \\
\text { Duyên Hải, huyện Hưng Hà }\end{array}$ & 633921 & 2282062 & 69 & 35,8 & 7,5 & 375,8 \\
\hline 27 & $\begin{array}{l}\text { Trần Đắc Bổn- Khả Tiến, xã Duyên Hải, } \\
\text { huyện Hưng Hà }\end{array}$ & 634021 & 2282042 & 100 & 36,9 & 7,58 & 370,2 \\
\hline 28 & $\begin{array}{l}\text { Nguyễn Văn Dũng-Khả Tiến, xã Duyên } \\
\text { Hải, huyện Hưng Hà }\end{array}$ & 633853 & 2282216 & 70 & 39,3 & 7,62 & 366,0 \\
\hline 29 & $\begin{array}{l}\text { Lê Xuân Nên-Khả Tiến, xã Duyên Hải, } \\
\text { huyện Hưng Hà }\end{array}$ & 633977 & 2282103 & 72 & 36,6 & 7,46 & 375,7 \\
\hline 30 & $\begin{array}{l}\text { Lê Xuân Bắc-Khả Tiến, xã Duyên Hải, } \\
\text { huyện Hưng Hà }\end{array}$ & 633780 & 2282239 & 100 & 40,4 & 7,53 & 365,0 \\
\hline 31 & $\begin{array}{l}\text { Lê Xuân Khương-Khả Tiến, xã Duyên } \\
\text { Hải, huyện Hưng Hà }\end{array}$ & 633903 & 2282079 & 80 & 39,3 & 7,45 & 356,1 \\
\hline 32 & $\begin{array}{l}\text { Nguyễn Hữu Đỉnh-Khả Tiến, xã Duyên } \\
\text { Hải, huyện Hưng Hà }\end{array}$ & 633994 & 2282364 & 75 & 37,8 & 7,39 & 374,0 \\
\hline 33 & $\begin{array}{l}\text { Lê Xuân Cung-Khả Tiến, xã Duyên Hải, } \\
\text { huyện Hưng Hà }\end{array}$ & 633729 & 2282095 & 70 & 41,9 & 7,34 & 352,3 \\
\hline 34 & $\begin{array}{l}\text { Nguyễn Hữu Đón-Khả Đông, xã Duyên } \\
\text { Hải, huyện Hưng Hà }\end{array}$ & 633758 & 2281891 & 75 & 39,0 & 7,17 & 357,4 \\
\hline 35 & $\begin{array}{l}\text { Phùng Văn Chi-Khả Tân, xã Duyên Hải, } \\
\text { huyện Hưng Hà }\end{array}$ & 633405 & 2282063 & 70 & 42,6 & 7,64 & 356,9 \\
\hline 36 & $\begin{array}{l}\text { Phùng Văn Hân-Khả Đông, xã Duyên } \\
\text { Hải, huyện Hưng Hà }\end{array}$ & 633691 & 2281741 & 70 & 38,3 & 7,38 & 362,5 \\
\hline 37 & $\begin{array}{l}\text { Nguyễn Kim Việt-Khả Tân, xã Duyên } \\
\text { Hải, huyện Hưng Hà }\end{array}$ & 633089 & 2281933 & 80 & 45,5 & 7,77 & 344,6 \\
\hline 38 & $\begin{array}{l}\text { Lê Xuân Khương-Giếng dự án Úc khoan, } \\
\text { Khả Tân xã Duyên Hải, huyện Hưng Hà }\end{array}$ & 633083 & 2281945 & 110 & 48,1 & 7,95 & 344,3 \\
\hline 39 & $\begin{array}{l}\text { Bùi Anh Tuấn -Khả Tiến, xã Duyên Hải, } \\
\text { huyện Hưng Hà }\end{array}$ & 632541 & 2281955 & 80 & 39,0 & 7,09 & 363,5 \\
\hline 40 & $\begin{array}{l}\text { Nguyễn Văn Khởi-Bùi Minh, xã Duyên } \\
\text { Hải, huyện Hưng Hà }\end{array}$ & 632149 & 2282365 & 75 & 38,5 & 7,15 & 359,7 \\
\hline 41 & $\begin{array}{l}\text { Bùi Văn Lập-Bùi Việt, xã Duyên Hải, } \\
\text { huyện Hưng Hà }\end{array}$ & 631860 & 2282517 & 75 & 34,7 & 7,29 & 372,1 \\
\hline 42 & $\begin{array}{l}\text { Bùi Huy Việt-Bùi Minh, xã Duyên Hải, } \\
\text { huyện Hưng Hà }\end{array}$ & 631651 & 2282192 & 70 & 30,1 & 7,05 & 384,8 \\
\hline 43 & $\begin{array}{l}\text { Nguyễn Năng Thịnh-Văn Quan, xã } \\
\text { Duyên Hải, huyện Hưng Hà }\end{array}$ & 631377 & 2281564 & 70 & 28,9 & 6,87 & 391,7 \\
\hline 44 & $\begin{array}{l}\text { Bùi Huy Hoài-Bùi Tiến, xã Duyên Hải, } \\
\text { huyện Hưng Hà }\end{array}$ & 631186 & 2282497 & 70 & 28,9 & 7 & 397,7 \\
\hline
\end{tabular}




\begin{tabular}{|c|c|c|c|c|c|c|c|}
\hline 45 & $\begin{array}{l}\text { Vũ Văn Dụng-Vân Cẩm, xã Duyên Hải, } \\
\text { huyện Hưng Hà }\end{array}$ & 631651 & 2282192 & 80 & 29,5 & 6,97 & 412,5 \\
\hline 46 & $\begin{array}{l}\text { Nguyễn Văn Trường-Chí Linh, xã Đông } \\
\text { Đô, huyện Hưng Hà }\end{array}$ & 633018 & 2279707 & 40 & 28,3 & 6,52 & 411,4 \\
\hline 47 & $\begin{array}{l}\text { Nguyễn Duy Phụng-thôn Hữu, xã Đông } \\
\text { Đô, huyện Hưng Hà }\end{array}$ & 633939 & 2279603 & 120 & 27,8 & 6,95 & 429,2 \\
\hline 48 & $\begin{array}{l}\text { Nguyễn Văn Đoàn-Tân Dân, xã Bắc Sơn, } \\
\text { huyện Hưng Hà }\end{array}$ & 633639 & 2279925 & 60 & 28,1 & 6,71 & 416,9 \\
\hline 49 & $\begin{array}{l}\text { Trần Xuân Phú-xóm Minh Đức, xã Bắc } \\
\text { Sơn, huyện Hưng Hà }\end{array}$ & 634313 & 2279862 & 94 & 27,4 & 6,8 & 429,2 \\
\hline 50 & $\begin{array}{l}\text { Vũ Văn Đại-xã Cộng Hòa, huyện Hưng } \\
\text { Hà }\end{array}$ & 634520 & 2280516 & 105 & 28,0 & 6,61 & 404,3 \\
\hline 51 & $\begin{array}{l}\text { Phạm Thanh Hải-An Khoái, xã Quỳnh } \\
\text { Sơn, huyện Quỳnh Phụ }\end{array}$ & 635575 & 2283275 & 96 & 26,9 & 7,3 & 421,6 \\
\hline 52 & $\begin{array}{l}\text { Bác Tuấn-An Khoái, xã Quỳnh Sơn, } \\
\text { huyện Quỳnh Phụ }\end{array}$ & 635050 & 2283202 & 90 & 27,0 & 7,25 & 415,9 \\
\hline 53 & $\begin{array}{l}\text { Nguyễn Quang Huy-Thượng Thọ- Am } \\
\text { Khoái, xã Quỳnh Sơn, huyện Quỳnh Phụ }\end{array}$ & 635186 & 2284058 & 50 & 26,5 & 7,17 & 438,3 \\
\hline 54 & $\begin{array}{l}\text { Nguyễn Xuân Tình-Cẩm Du, xã Quỳnh } \\
\text { Sơn, huyện Quỳnh Phụ }\end{array}$ & 634226 & 2284076 & 100 & 27,5 & 7,13 & 417,3 \\
\hline 55 & $\begin{array}{l}\text { Phạm Văn Sự-Cẩm Du, xã Quỳnh Sơn, } \\
\text { huyện Quỳnh Phụ }\end{array}$ & 633539 & 2284336 & 70 & 28,6 & 7,26 & 414,1 \\
\hline 56 & $\begin{array}{l}\text { Vũ Thanh Hải-Hạ Tây, xã Quỳnh Ngọc, } \\
\text { huyện Quỳnh Phụ }\end{array}$ & 632393 & 2284040 & 80 & 30,2 & 7,31 & 393,8 \\
\hline 57 & $\begin{array}{l}\text { Vũ Đình Tấn-Quỳnh Lay, xã Quỳnh } \\
\text { Ngọc, huyện Quỳnh Phụ }\end{array}$ & 631491 & 2284554 & 80 & 31,0 & 7,28 & 377,9 \\
\hline 58 & $\begin{array}{l}\text { Trần Văn Hùng-Đông Châu, xã Quỳnh } \\
\text { Ngọc, huyện Quỳnh Phụ }\end{array}$ & 630751 & 2284797 & 75 & 29,7 & 7,18 & 385,7 \\
\hline 59 & $\begin{array}{l}\text { Nguyễn Đức Thoa-Đông Châu, xã Quỳnh } \\
\text { Ngọc, huyện Quỳnh Phụ }\end{array}$ & 630813 & 2285238 & 65 & 28,9 & 7,32 & 391,1 \\
\hline 60 & $\begin{array}{l}\text { Nguyễn Thị Đoàn-Tân Mỹ, xã Quỳnh } \\
\text { Ngọc, huyện Quỳnh Phụ }\end{array}$ & 630289 & 2286164 & 65 & 29,0 & 7,08 & 387,2 \\
\hline 61 & $\begin{array}{l}\text { Bùi Văn Ngọc-thôn Phú Hợi, xã Dân } \\
\text { Chủ, huyện Hưng Hà }\end{array}$ & 631283 & 2283986 & 65 & 30,7 & 7,21 & 388,5 \\
\hline 62 & $\begin{array}{l}\text { Nguyễn Đình Thi-Đan Hội, xã Dân Chủ, } \\
\text { huyện Hưng Hà }\end{array}$ & 631527 & 2283648 & 70 & 33,9 & 7,55 & 379,2 \\
\hline 63 & $\begin{array}{l}\text { Nguyễn Văn Anh -thôn Đinh, xã Dân } \\
\text { Chủ, huyện Hưng Hà }\end{array}$ & 631820 & 2283886 & 100 & 33,9 & 7,37 & 385,9 \\
\hline 64 & $\begin{array}{l}\text { Đinh Văn Quân-thôn Đinh, xã Dân Chủ, } \\
\text { huyện Hưng Hà }\end{array}$ & 632026 & 2283130 & 80 & 34,4 & 7,39 & 375,9 \\
\hline 65 & $\begin{array}{l}\text { Nguyễn Xuân Vân-thôn Ngọc, xã Dân } \\
\text { Chủ, huyện Hưng Hà }\end{array}$ & 632287 & 2282943 & 65 & 34,1 & 7,22 & 375,2 \\
\hline 66 & $\begin{array}{l}\text { Phạm Quốc Khấn-Hà Tiến, xã Dân Chủ, } \\
\text { huyện Hưng Hà }\end{array}$ & 630605 & 2284763 & 70 & 29,9 & 7,13 & 378,7 \\
\hline 67 & $\begin{array}{l}\text { Nguyễn Văn Tài-Ngũ Đông, xã Điệp } \\
\text { Nông, huyện Hưng Hà }\end{array}$ & 629646 & 2284710 & 65 & 32,4 & 7,18 & 379,9 \\
\hline
\end{tabular}




\begin{tabular}{|c|l|c|c|c|c|c|c|}
\hline 68 & $\begin{array}{l}\text { Nguyễn Xuân Cao-Ngũ Đàn, xã Điệp } \\
\text { Nông, huyện Hưng Hà }\end{array}$ & 629329 & 2284590 & 68 & 33,3 & 7,37 & 381,2 \\
\hline 69 & $\begin{array}{l}\text { Nguyễn Văn Hường-Việt Yên 4, xã Điệp } \\
\text { Nông, huyện Hưng Hà }\end{array}$ & 628521 & 2284694 & 70 & 34,5 & 7,17 & 380,7 \\
\hline 70 & $\begin{array}{l}\text { Hoàng Văn Thêm-Duyên Nông, xã Điệp } \\
\text { Nông, huyện Hưng Hà }\end{array}$ & 628191 & 2283978 & 70 & 29,0 & 7,24 & 388,8 \\
\hline 71 & $\begin{array}{l}\text { Nguyễn Văn Quân-Hoàng Nông, xã Điệp } \\
\text { Nông, huyện Hưng Hà }\end{array}$ & 627459 & 2283520 & 68 & 29,3 & 7,25 & 401,7 \\
\hline 72 & $\begin{array}{l}\text { Phan Văn Của-thôn Trung Đẳng, xã Hùng } \\
\text { Dũng, huyện Hưng Hà }\end{array}$ & 629347 & 2282566 & 70 & 29,0 & 7,15 & 397,9 \\
\hline 73 & $\begin{array}{l}\text { Nguyễn Mạnh Hồng-Hà Lý, xã Hùng } \\
\text { Dũng, huyện Hưng Hà }\end{array}$ & 629514 & 2281885 & 70 & 30,5 & 7,01 & 459,9 \\
\hline 74 & $\begin{array}{l}\text { Vũ Duy Khương-Nhân Phú, xã Hùng } \\
\text { Dũng, huyện Hưng Hà }\end{array}$ & 629782 & 2281037 & 45 & 30,1 & 7,13 & 466,2 \\
\hline 75 & $\begin{array}{l}\text { Phạm Văn Luyện-Nhân Phú, xã Hùng } \\
\text { Dũng, huyện Hưng Hà }\end{array}$ & 630385 & 2281691 & 45 & 30,5 & 7,08 & 486,8 \\
\hline 76 & $\begin{array}{l}\text { Vũ Minh Tôn-thôn Cẩm, xã Hùng Dũng, } \\
\text { huyện Hưng Hà }\end{array}$ & 630669 & 2282410 & 70 & 29,9 & 7,15 & 430,8 \\
\hline 77 & $\begin{array}{l}\text { Nguyễn Đăng Toán-Ngọc Liễu, xã Hùng } \\
\text { Dũng, huyện Hưng Hà }\end{array}$ & 630403 & 2280541 & 78 & 30,9 & 7,01 & 407,8 \\
\hline 78 & $\begin{array}{l}\text { Vũ Xuân Tín-Chung Đình, xã Văn Cẩm, } \\
\text { huyện Hưng Hà }\end{array}$ & 631288 & 2280655 & 70 & 31,5 & 7,23 & 414,2 \\
\hline 79 & $\begin{array}{l}\text { Đố Xuân Đưởng-Trần Xá, xã Văn Cẩm, } \\
\text { huyện Hưng Hà }\end{array}$ & 632568 & 2280709 & 80 & 35,2 & 7,04 & 387,6 \\
\hline 80 & $\begin{array}{l}\text { Đỗ Xuân Bằng -Trần Xá, xã Văn Cẩm, } \\
\text { huyện Hưng Hà }\end{array}$ & 632953 & 2280843 & 86 & 40,4 & 7,48 & 369,3 \\
\hline
\end{tabular}

